\title{
O cinema como errância - os deslocamentos como objetos: o documentário aforístico de Llorenç Soler
}

\author{
Rafael Tassi Teixeira*
}

Resumo: O trabalho incursiona pela reflexão teórico-analítica das composições fílmicas de um dos pioneiros do cinema documental ensaístico na Espanha, buscando aproximações entre os discursos fílmicos e a análise da obra teórica do cineasta valenciano Llorenç Soler; tenta tecer articulações entre as narrativas cinematográficas, as estilísticas documentais e a convergência biográfica-performativa das obras do cineasta.

Palavras-chave: documentários em primeira pessoa; teoria dos cineastas; Llorenç Soler.

Resumen: El trabajo se adentra en una reflexión teórico-analítica de las composiciones fílmicas de unos de los pioneros del cine documental ensayístico en España, en busca de relaciones entre los discursos fílmicos y la obra teórica del director valenciano Llorenç Soler. Trata, así, de tejer vínculos entre las narraciones cinematográficas, las estilísticas documentales y la convergencia biográfico-performativa de las obras del cineasta.

Palabras clave: documentales en primera persona; teoría de los cineastas; Llorenç Soler.

\begin{abstract}
The work is based on the theoretical-analytical reflection of the film compositions of one of the pioneers of the documentary essay film in Spain, seeking approximations between the filmic discourses and the analysis of the theoretical work of the Valencian filmmaker Llorenç Soler; it attempts to weave articulations between cinematographic narratives, documentary stylistics and the biographical-performative convergence of the works of the filmmaker.
\end{abstract}

Keywords: first person documentaries; filmmakers' theory; Llorenç Soler.

Résumé : Ce travail se risque dans la réflexion théorique et analytique des compositions filmiques d'un pionnier du film documentaire d'essai en Espagne, à la recherche de similitudes entre le discours et l'analyse de la théorie du travail du cinéaste valencien Llorenc Soler, tout en essayant de tisser des liens entre le récit cinématographique, les stylistiques documentaires et la convergence biographico-performative des œuvres du cinéaste.

Mots-clés : documentaires en première personne ; théorie des cinéastes ; Llorenç Soler.

* Universidade Estadual do Paraná - UNESPAR, Faculdade de Artes do Paraná, Campus II / FAP. 80035000, Curitiba (Paraná), Brasil. E-mail: rafatassiteixeira@ hot mail.com

Submissão do artigo: 13 de março de 2017. Notificação de aceitação: 10 de julho de 2017.

Doc On-line, n. 22, setembro de 2017, www.doc.ubi.pt, pp. 257-272. 


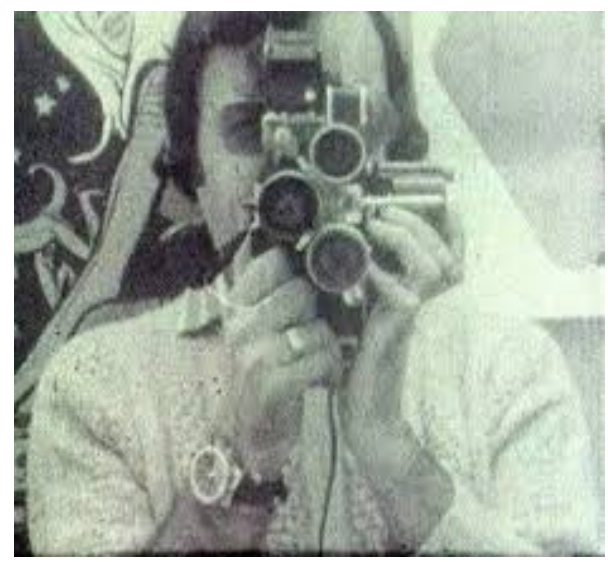

Figura 1. Llorenç Soler

\section{A escritura das imagens no limite do relato: propor a fuga e estar consciente da sua espera}

Pensar a imagem como um componente da rotina de sua perda, constante, irreparável. Pensar o tempo como investido de limites, contraditórios, sobreviventes. Pensar os limites como processos de experiência - frequentá-los por suas redundâncias, margeá-los por suas distorções, reconhecê-los em seus descobrimentos.

O cinema de Llorenç Soler, ${ }^{1}$ atravessando mais de quatro décadas diante de uma frágil e ao mesmo tempo segura constatação - os limites da imagem como os limites da fronteira entre a observação e a sua espera -, revela-se, em uma perspectiva da incompletude, pela profícua criação poética diante tudo o que precisa ser dito e diante de tudo que não tem como ser revelado. Revelação, a não ser como uma poesia, vacilante e imprescindível, do valor (insubstituí-

1. Llorenç Soler nasce em Valencia (1936) e desenvolve suas atividades de diretor, realizador de documentários para cinema e televisão, professor (Escola de Valencia) e teórico de cinema, pintor e poeta, ensaísta e 'homem das margens', como ele mesmo gosta de declarar-se, ao longo de mais de quatro décadas de trabalhos como artista comprometido com um pensamento social. A força de seu olhar como cineasta, enfatizado principalmente em seus trabalhos como documentarista em mais de quatro décadas e meia de cinema fronteiriço, aparece em mais de cem obras audiovisuais, desde filmes fundamentais de sua primeira etapa como documentarista: 52 Domingos (1967), El largo viaje hacia la ira (1969), Sobrevivir en Mauthausen (1975), Gitanos sin romanceiro (1976), etc., à filmes mais recentes sobre ensaios poéticos e reflexões de personagens esquecidos: Francisco Boix: Un Fotógrafo en el Infierno (2000), Max Aub: Un Escritor en su Labirinto (2002), Del Roig al Blau (2005), El hombre que sonreía a la muerte (2006), Veinte proposiciones para un silencio habitado (2007); além disso, tem três obras de ficção em longa-metragens: Said (1999), Lola vende cá (2000) e Vida de família (2007) e uma extensão obra ensaística-conceitual em livros sobre teoria do documentário. 
vel) de uma única e mesma (repetida ao infinito) falta: a imagem não substitui, mas sim alimenta, incide, permanece e retrocede sobre a condição errante - do documentarista, do cineasta como observador injusto e como personagem verdadeiro. Um cinema da impossibilidade de sentir-se outra coisa senão como fronteira de si mesmo. Um cinema, com as margens como insistências, porque muda, constantemente, de lugar diante das pequenas práticas, dos pequenos limites dessa vontade - não de captura - mas do silenciar sobre a gramática da ausência (da imagem e suas representações partidas). O cinema, portanto, que é limite de si mesmo, ao dilatar a abertura e o distanciamento do olhar para não ter medo de nele permanecer:

... era una experiencia que se situaba decididamente en los márgenes del género, en un terreno fronterizo de difícil clasificación. (Años más tarde comprendí que las propuestas más interesantes ocurren siempre en la frontera). Cuando rodé mi largometraje Lola vende cá, logré instalarlo en una tierra de nadie que lo hizo más atractivo. Pero yo, en 1970, ignoraba todavía el resultado de mis propias experiencias y, en todo caso, me movía a impulsos de mis intuiciones. (Soler, 2002: 52).

Cinema que desprende os limites entre documentário e ficção desde os primeiros movimentos, porque não acredita em nada que não seja o reflexo de uma identidade em relação, de um caminho aberto, preocupado com "a escritura que se constrói nas margens e na marginalidade" (Català, 2012). Assim mesmo, um cinema de enfrentamentos, da incapacidade em ser uma representação reduzida de algo que sempre, em Soler, está estabelecido pela durabilidade do alcance do sentido de experiência ${ }^{2}$.

Nesse aspecto, a permanência 'fiel' no documentário (em tudo o que ele é infiel), em um cineasta que avança sobre o comprometimento com as "experiências de difícil classificação" (Soler, 2002): a imagem é, nesse sentido, poderosamente movida pelo sentido da vibração do que é mais indeterminado ou de difícil classificação. Estabelecer um elemento de familiaridade em algo que se estabelece, por si só, na proximidade desconfortável, revelando-se em territórios de coincidência improvável, de insistência dinâmica e fronteiriça.

O filme, nesse aspecto, como propõe Comolli (2008), está sempre sob suspeita, porque se vertebra na diversidade de pontos de vista; porque, pela pausa e pela escuta, no caso de Soler, pela escrita, pelo desenho, pela relação com a poesia e com a pintura (o cineasta é, ao mesmo tempo, pintor, gravurista, poeta,

2. A figuração de histórias que tem a ver com o processo de descobrimento do poder do relato, e da intensidade da experiência humana em suas configurações mais inquietas, pois os temas frequentemente tocam a duração difícil da história (anônima) dos rostos, da preferência pelo tratamento desretilíneo, em uma "escritura en imágenes" pelos sujeitos de suas próprias condições históricas, produtos de uma estrutura sob a ameaça constante de anulação e apagamento. 
ensaísta e teórico de cinema), dissemina-se buscando sempre as franjas de um processo de derramamento. A subjetividade, em seus dois polos - o elemento mais justo de se tratar um filme, segundo Soler -, incide sobre a relação entre documentarista e artista, cinema e cineasta, observador e observados, sujeitos fílmicos e sujeitos ausentes.

Se o autor chega a compenetrar-se com o sentido profundo dos sucessos que narra, a identificar-se com eles, a senti-los como próprios, poderá construir uma realidade fílmica que resultará perfeita e adequadamente verossímil... Se o documentário não é a verdade, ou, ao menos, toda a verdade, o discursos de significados que emana da estrutura da montagem sim pode aproximar-nos da verdade que o realizador pretende comunicar... A subjetividade do autor está sempre presente. (Soler, 1998: 40).

Dessa ausência indizível que é a escrita fílmica - por sempre achar que tem o poder de recuperar um papel e viver entre o território do imaginal e a disputa de significações/identificações, o filme emerge como uma batalha por ocasiões da fala, da escuta e de uma espera (limite de sua entrega, sempre a acontecer). O cineasta como autor espelho do artista como documentarista, dessa forma, invade a fronteira, o sentido e a relação, para neles permanecerem. Nesse sentido, Soler expressa essa incapacidade sistêmica em descrever o que não pode ser descrito diante dos limites do cinema:

¿Qué es el 'documental de creación, también llamado de autori[...] es redundante hablar de documental de creación, por la misma razón que no nos referimos a la novela de creación, o la música de creación. (Soler, 2002: 114).

Da realidade sob múltiplas formas, da crônica social comprometida e, sobretudo, do cinema como errância, os exercícios de imagem que refletem o desejo de impor uma lógica cinematográfica - entre o metafórico e o orgânico - que revelam, por um lado, a dessacralização do autor, e, por outro, permitem sua verossimilhança: a mutação do desejo de 'revelar o irrevelável' no cinema para uma comunicabilidade em constante indeterminação. O filme, como uma espécie de 'jogo derramado', de "ficção séria" 3 , trazendo para o centro do debate uma epistemologia da criação da subjetividade, prolifera a intersecção artista-obra, comunicação-arte, jogos de cena e realidades fílmicas, sujeitos observadores e cineastas observados, etc.

Nesse âmbito, a proliferação de um pensamento experimental desde as origens de sua relação com o documentário, reverbera, em Soler, uma espécie de esforço em caracterizar-se pela fecundidade propositiva da imagem - pela errância, naquilo que ela traz de potente e inesperado. O filme trata da imagem como o documento dimensiona a palavra. Jogos múltiplos - em derivas e

3. Strathern (2013). 
multiplicações - que problematizam a insuficiência fílmica como linguagem: o ato cinematográfico potência do acontecimento relacional; a câmera que perde a posição preferencial para ensejar um discurso de descentramento e interação; o olhar que deixa de tentar nominar o inominável e repreender o fluxo do instante; o corpo que valoriza a palavra e sente-a como circulação, como crítica da crítica, como ruptura da determinância do representável (sabendo-o um jogo do real em imaginários).

Essa circulação constante do filme e seu desejo de conexão, em Soler, entretanto, tem mais a ver com a negação da indiferença (da ontologia da imagem) que a preocupação com superar seu espelho específico - o filme, mesmo em uma praxiologia da leitura como 'documentário', não perderá sua antinomia favorável ao julgamento crítico. Precisamente por estabelecer uma espécie de vínculo perdido entre o abrangente e o idiossincrático, ele - o documentário - torna-se menos dualização (de imagens) e mais circuitos de negociação (do tempo). ${ }^{4}$

Nesse aspecto, o prevalecer metonímico, depois de toda a imagem, significa, no cinema do cineasta, que a dissonância está no interior do movimento de captura da disposição dos "jogos de realidade e ficção" (Berzosa, 2012). Mas, também, revela-se no inesperado da possibilidade da interação entre os corpos filmados e o sujeito-da-câmera. Essas digressões podem ser pensadas como a iniciativa da imagem em proliferar e manter o regime de observações para além do resíduo cinematográfico - o filme que de certa forma enseja uma espécie de tensão entre o artifício e o real a todo momento, experiência criativa que emerge como território em que funciona como um rito de iniciação - o caleidoscópio da imagem (do fotograma) que segue incutido de possibilidades de relação, interpretação e circuitos de imaginários, sem impedir o deambular no interior da experiência cinematográfica - como uma recusa da ruptura entre a forma e a experiência. O 'tempo cinematográfico', em Soler, traz, dessa forma, sempre a possibilidade de fecundar o real sucessivas vezes, destruindo-o, em seguida, por infinitos mascaramentos, habitando-o em seus ritmos sub-reptícios. (Mas, também, acompanhando-o em unidades de relação no cotejamento com uma dimensão relacional.)

Um 'real', como jogo, ritual e demonstração, que se revela por pequenas peças, pequenos fragmentos além da intencionalidade da captura. Captura que não é outra senão a ideia de circuito, ou a expectativa por um cinema que

4. A temporalidade absoluta, que nasce da situação da espera; esperar é tudo em um universo de sobrevivência da imagem, apesar de sua política intrínseca de conexão (com outras imagens, com outros imaginários): "A ficção tem como vocação a construção de uma realidade. Enquanto que o documentário tende a sua destruição, a seu mascaramento, porque filma e registra somente as aparências da realidade. E, mesmo assim, permite-se interpretá-la”. (Soler, 2002: 08). 
esteja imbuído da experiência da pluralidade dos sentimentos, das imagens frente ao seu abandono, dos espaços diante de seus desconcertos; da decisão prolongada de distrair-se com a vocação para estar no limite (realidade-ficção, artista-documentarista, subjetividade-objetivismo), o filme se cria. Em cada plano, em cada comunicação que se propaga, a imagem remanesce sozinha demais para ser evocada como habitação da palavra. Ou seja, alimenta a ideia de que todo o documentário é intercedido pela natureza intrinsecamente inconstante, pela falibilidade de toda a narrativa (contra a evocação de todo o plano). De maneira propositiva, o cinema do cineasta se edifica na constituição poliédrica e se torna constantemente atento à perspectiva tanto pessoal como etnográfica - autoria e anonimidade trocando muitas vezes de lugar -; faz sua força na maneira como presencia sempre o diálogo entre ficção e realidade, preferencialmente nos limites entre estas duas costuras, inseparáveis, complementárias, descritas pela memória e recuperadas pela emancipação. ${ }^{5}$

Da relação entre o cinema e o documentário, a capacidade de dispor-se a escrever cinema através de sucessivos ciclos: personagens migrantes, ciganos, racializados pelos meios de comunicação, corpos sem presença, presenças profanadas em corpos que sobrevivem, cinemas de vestígios, cinemas dentro de aforismos como um jogo constante - e uma iniciação sempre a empreender-se - no processo de estar entre o ensaístico e o conceitual, entre a interpretação e sua ambivalência. ${ }^{6}$

Nesse sentido, a câmera é, para Soler, uma força centrípeta. Um lugar que a realidade é dilatada porque pode se perceber sempre de maneira lábil e inconstante: da insuficiência dos liames entre palavra e imagem, exaustivamente esperadas, que trazem para o centro do filme uma singularização relacional, uma necessidade atomística, um encontro (inesperado) estético. O filme revela os limites da capacidade em produzir pensamento e transgressão. ${ }^{7}$ Aqui, contudo, não se deseja agarrar àquilo que precisa disseminar ou expandir. So-

5. Seus filmes como mistura de entrevistas (desarticuladas da exigência e do absolutismo da representação), feito de longos fragmentos poéticos, sequências simbólicas, densas pausas e suas perfurações silenciosas, cinema de fronteiras que o próprio cineasta redime ao falar da experiência de viver constantemente atento ao independente: “... comprendí que las propuestas más interesantes ocurren siempre en la frontera" (Soler, 2002: 52).

6. A escrita e o relato, desde os filmes iniciais - Será tu tierra, 1965; 52 Domingos, 1967; D'un temps a outro, 1968; El largo viaje hacia la ira, 1969 - em que a ideia da representação imbrica-se com a força da experiência, obrigando o cineasta (pintor, poeta e diretor de fotografia) a derrubar antinomias e gerar circuito de vozes em que a perspectiva da fronteira e do encontro (da errância como indumentária imprescindível) tem o efeito de desdramatizar o sentido e potencializar o encontro.

7. Colocamos, aqui, todos os ciclos, pois os filmes do cineasta são, desde os documentários com vocação para uma antropologia da urgência na década de 1960, aos últimos filmes-haikais do final do século passado, expressos menos por qualquer unidade - que seria sempre falsa e contraditória em Soler - temática e estilística, mas que convergem para um mesmo pensamento sobre cinema e imagem, sobre enquadramento e fugacidade, sobre pintura (lembrando sempre de sua atividade como pintor) e revelação, sobre política e cotidiano, sobre migração e vida... 
bre os limites da singularidade da produção de uma estesia - filmar é produzir estesias um pouco mais seguras que aquelas que existem no cotidiano - o ato cinematográfico conjuga a semelhança da imagem (Didi-huberman, 2015) e a plenitude de sua espera. Esperar, que num tempo de ciclos de invisibilidades - sobre as marcações da ausência -, permite a imprevisibilidade do gesto (que atente à articulação do observável com a alegoria que o tenta surpreender). Filmar, portanto, tem a ver com um ensaio sobre a denominação de um trabalho de depuração da dinâmica da necessidade de frequentar a fronteira (o Eu e o Outro) mediado pelo ato fílmico como potência da relação participativa. Mas, também, ato, densidade, força, emergência que corrobora com a organização de um mundo que só pode ser conhecido pela interação com certa 'lucidez cinematográfica' disposta pela câmera. ${ }^{8}$

O conceito de documentário no cineasta valenciano expressa, notadamente, essa articulação entre a densidade fílmica e a filiação corpo-imagem-observador. Um observador que compreende - e não ingenuamente deseja revelar - um mundo de interposições dialéticas: a força da imagem tende a dissecar a natureza (incompreendida) da relação, mas (filmar) é um ato de exclusão determinante, porque subjuga o conhecimento à duplicidade de uma zona dos sentidos que se instaura na dimensão do plano. A natureza intrinsecamente perscrutadora da objetiva da câmera, não obstante, tem seu poder diluído ao concentrar-se na produção da espera, no jogo de relações entre o dizível e o invisível, no emancipar dos rostos em sucessivos primeiros planos, sob o silêncio de seus personagens (León, 2012). ${ }^{9}$

Dessa organização do efeito do documentário sobre a recusa em exigir narrativa e figuração prévias, o cineasta busca o questionamento da densidade dos pequenos espaços de observação com que as histórias do cotidiano são abraçadas. Entre o interesse em buscar a câmera como meio de produzir desnaturalizações sobre a complexidade do efeito aglutinador e enclausurante da metalinguagem - intuída quando se está habitada, perdida quando se pressupõe funcional -, o filme é uma forma de penetrar (errar, surpreender, circunvalar) o âmbito de uma relação que, acompanhada pela câmera, tem uma capacidade de elevar a produção da espera e diminuir desconfianças. Nesse sentido, a câmera é dirigida menos como epifania do registro e mais como escrita da relacionalidade adjacente, tensionada pela parcialidade que a desfaz, como se o compromisso fosse antes com a tradição de liberdade e densidade artística que

8. “... siguiendo a Rosellini, que el cine es un instrumento que "ha de servir al hombre para conocerse mejor'."(Soler, 2006: 254).

9. O cineasta estabelece uma associação importante ao escrever sobre pintar e filmar: “... allí donde el pintor añade, allí donde actúa por sumas, el operador de cámara lo hace por eliminación. El pintor incluye. Este, excluye." (Soler, 1998: 84). 
com o pensamento simplificado de uma objetividade ou uma representação que se esquecem das derivas observadores-observados/observação-interpretação.

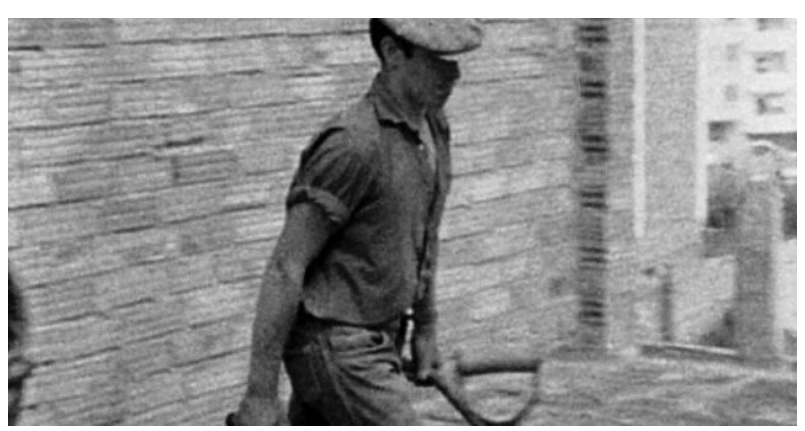

Figura 2. Fotograma de El largo viaje hacia la ira, 1969

O artista, portanto, é aquele que interpõe o sentido na ruptura de uma normalidade efeito de uma relação previsível - e, ao preencher de atenção os detalhes de uma (escrita) sobre imagens, o filme se torna um encontro, proliferação de movimentos que se gestam pela pausa, pela liberdade, pela desobjetificação parcial que a câmera produz. A câmera-olho é, nesse sentido, um intensificador daquilo que pode se tornar relação e das coisas que podem ter seu detalhamento explicitado; ou seja, a subjetividade do cineasta instrui o mundo como um recurso de acessibilidade em poéticas de compartilhamento que são sempre surpreendentes porque o cotidiano é lido como uma fonte (inesgotável, viva) de fronteirizações com a experiência. Fora da dimensão da temporalidade, o filme pode ser uma relação de distanciamento. Aproximações entre o vivido e o inobservável. Situações de inacabamento. Potencialidades de pequenos descentros, de mínimas histórias, de incontáveis interesses em partilhar o nãodito e o sobrecarregado. (O filme, nesse modo de interação densificado pela errância, estabelece limites que se auguram na estranheza como memória e na familiaridade como perspectiva). ${ }^{10}$

Para Soler, uma relação de fronteira é, portanto, uma relação de escritura de ausências. A proposta de um filme sem margens, sem começos prontos, sem finais sempre prestes; filmes (documentários) que são verdadeiramente independentes porque tem a dignidade de perder o controle quando são produzidos

10. Um dos múltiplos filmes de Soler que podemos usar como exemplo, El Poso de los Días (2009), a imagem decomposta revela-se na insuficiência da espera: uma série de micro relatos especificamente densificados pela observação sutil, em pensamentos espontâneos, em sentidos detalhados, escritos filmicamente a modo de aforismos sobre a memória que se imprime tenuamente: desde um bonsai que morre a um pássaro que renega sua liberdade em uma jaula pequena, chegando ao banco de um parque que desaparece e retorna novamente... 
O cinema como errância - os deslocamentos como objetos: o documentário aforístico de Llorenç Soler

como processos de espera, de escuta, de uma multiplicidade de dinâmicas de distanciamentos:

Sua natureza é falsa, tanto quanto fundamenta seu discurso narrativo na fragmentação da realidade, na unidirecionalidade da mirada (axial) da câmera, e na reordenação tendenciosa - pelo subjetivo - de todo material obtido... a tergiversação forma parte inseparável, consubstancial da existência mesma do gênero. (Soler, 1998: 26).

As narrativas cinematográficas, as estilísticas documentais e a convergência social-ficcional das obras do cineasta, concentram-se em sucessivos alinhamentos perspectivos sobre uma sistemática fílmico-reflexiva que enseja os limites da linguagem na dimensão da primeira pessoa. $\mathrm{O}$ autor, instruído pela imagem-memória ou pela imagem-relação, compreendendo o cinema como uma intersecção não programada entre a imaginação e sua escuta, entre realidade e potência, entre fabulação e discurso sobre uma realidade sempre em indeterminação, coloca-se inevitavelmente sempre prestes, da mesma forma que o filme, diante de um espelho - do olho do cineasta - será sempre perscrutador, mas também divisível: entregue a forma efetiva da abrangência de significados. Dessa 'natureza imprecisa', relacional, etérea e ao mesmo tempo concentrada das formas fílmicas, o tempo cinematográfico em Soler justapõe a inversão, a teoria da expectativa, a subjetiva participação em tudo que adquire circunstância e veracidade pelo tratamento sempre diante de uma possibilidade de adiar certa escolha; e, da escolha infinita, a escolta de um significado que se perde porque a imagem que se recorda é sempre a imagem que não permite estar pronta; ou, estrangeiramente, a imagem que se assemelha a sua natureza provisória, sensível, expectante, disponível, prestes.

Assim, em 20 Proposiciones para un silencio habitado (2007), há lugar para tudo através de uma inscrição faltante. A marca, o vazio insistente e também indelével da história da condição - improvável, premente, sempre precoce e aterrissada sobre si mesma - da imagem (do fotograma sobrevivente, da metaforização da representação). Documentário que é, no fundo, sobre a construção do silêncio em uma galeria de arte, o filme desenvolve-se diante de corpos que olham e são olhados, diante de uma sucessiva persistência de fotografias e um livro publicado por um coletivo de fotógrafos sorianos. Em forma de poema visual, a película se identifica com a capacidade de perder os espaços de realidade que se definem pela desorientação curiosa (pelo comprometimento espontâneo). Já em Autorretrato (2007), um jogo de imagens sobre a construção da trajetória como cineasta, funciona como um filme-espelho, pequeno movimento experimental de pouco mais de dez minutos que revela uma espécie de diagrama holográfico da história de Soler no cinema. Peça de biografia sobre a memória em imagens que sobraram de filmagens anteriores, 
funciona como uma tramitação da experiência em um tratamento desfigurativo de seu próprio fazer como cineasta. Autorretrato é, portanto, um filme que vai até a ancestralidade para descobrir que não há, unicamente, apenas uma voz própria, mas, sim, uma errância, novamente - fixada pela insistência em entrar no imaginário, em percorrer o sentido observado a irrealidade que tudo conduz. Aqui, o tempo, o exílio e a demora sobre um silêncio - desejo de ser anônimo ou desejo de relativizar o gosto - torna-se superfície que se investiga porque o sujeito (o autor, o cineasta) interpõe múltiplas mediações (tempo e circunstância, passado e presente, autoria e anonimidade, lugar e memória,) na vontade de lutar para que a impermeabilidade das fronteiras não exista.

Projeto estético de composição associativa entre o corpo do cineasta e a 'pele' do filme, Autorretrato é narrado em primeira pessoa e pensado para ser um campo de jogos entre o visível (indisponível) e o aparente (improvável). Filme carregado de primeiros planos, dentro da visão de um espelho que habita vários fotogramas. Espelho (s), que reflete (m) o rosto do cineasta, ao olhar frontalmente a câmera, ao deixar ser ele mesmo investigado pelos limites e impossibilidades da representação. Um cinema de reflexos que adentra a memória da incapacidade em lembrar, sem perder a presença. Uma presença fílmica, cinemática - que dessacraliza a autoridade cinematográfica por preferir percorrer os liames da experiência da dimensão artística, das condições da existência da impossibilidade de mensagens e obsessões narrativas em tudo. ${ }^{11}$

Nesse sentido, se a arte é o meio para a expressividade do conhecimento que se coloca, inevitavelmente, como uma ideia de cinema entre a experiência subjetiva - educada pela imagem cinematográfica e pelas relações estilísticas com os cineastas admirados ${ }^{12}$, o filme é um produto de uma história sobre uma espera que, ainda e sempre, precisa ser escrita. Relação de indissociabilidades (fruição estética e as condições para sua existência), formas que se misturam com engajamentos que se precisam, o filme, nesse aspecto, contesta, a todo instante, a sedução de uma autenticidade que se costura porque a intersecção - ensaio, biografia, memória, sentimento, olho - está sempre na natureza cêntrica de cada documentário construído ${ }^{13}$.

11. Talvez, em Soler, pela proximidade e gosto pela pintura, pela escrita e publicação de poemas, pela forma de 'pequenos aforismos visuais' (Francés, 2012) ilustrem a densidade de um cinema-mosaico (impregnado de solipsismos visuais, interpretação e teoria, observação e escuta artístico-etnográfica).

12. Soler declaradamente perpassa a história do cinema (Romeguera I Ramió, Soler, 2006) através de autores que nutre admiração e busca influencia: Flaherty, Murneau, Pasolini, Antonioni...

13. E, nesse aspecto, não há corrupção maior que o documentário como gênero que, segundo Soler, 'destrói' a realidade escondendo sua evocação: "A ficção tem como vocação a construção de uma realidade. Enquanto que o documentário tende a sua destruição, a seu mascaramento, porque filma e registra somente as aparências da realidade. E, mesmo assim, permite-se interpretá-la”. (Soler, 2002: 8) 
O cinema como errância - os deslocamentos como objetos: o documentário aforístico de Llorenç Soler

Se, como diz Soler, "O documentário não é nada mais que o resultado de um conjunto de restrições técnicas e de opções de representação" (Soler, 1998: 212), há de se pensar que existe encenação, sempre. A própria dimensão da espectorialidade cinemática do olhar do autor sobre outras autorias (e não apenas registros, mas relatos potentes que são memórias interpretadas de si mesmo), impõe a aproximação com o tempo (registro), mas também com a imagem (propagação). De certa forma, a natureza do documentário está em, assim, totalizar o real sem querer revelá-lo - ou mostrando-o parcialmente. Inútil, vai dizer o cineasta, porque "um documentário é um trabalho indeciso, trêmulo, contraditório, seguramente errôneo, sobre uma realidade" (Soler, 1998: 251). Do mesmo modo, a arte é, conforme Bourdieu (1996), produto da história, reproduzida pela educação. Entretanto, fazer refletir a profanação da história dessa relação (memória-imagem, escrita-tradição, documentáriorealidade), não pode ser visto em oposição ao mundo da vida cotidiana: sagrado em relação a profano, objeto em relação a sujeito, subjetividade em separação à observação.

Encobrimento do real, como diz o cineasta, o filme documentário revela-se um mosaico de impulsos sobre uma vontade de metaforizar o instante. Peça de um labirinto, espécie de lugar em que a alteridade - todas elas, em suas potências e expectativas tanto intensificadoras como descontruídas -, enuncia-se pela falibilidade da experiência da constatação das suas características supostamente perenes. A organização fílmica, portanto, passa por não esconder a intencionalidade original, historiando o processo de construção enunciativo. Filmar é, dessa maneira, agarrar uma memória que, sem direção, perderia sua capacidade de associar-se com o caráter provisório de toda a relação. (E até a relação fílmica, para Soler, também se dá desse jeito.)

Monólogos de un hombre incierto (2010), por sua vez, diagrama essas questões ao procurar a fronteira, ou a desclassificação, sempre. Filme de discursos e estados de ânimo do autor em cada circunstância, revelando como as discussões sobre sensibilidade estética são instruídas pela contingência em uma criação que está em tudo, como voz e como escuta. Em forma de breviário, como escritas subjacentes ao deslocamento enunciativo ao longo de cada plano, Monólogos revela todos os limites, potências, falta de controles, rebeldias casuísticas, afeição à derivas e liberdades misturadas no plano do detalhe e no plano do abrangente. Tudo isso, para fugir da normatividade plena, da teorização sem lugar ao vestígio e ao escapatório, ao que é resto e o que resta dentro e fora da imagem: essa característica efusivamente prescritiva da forma artística para se chegar ao abrangente, do mesmo modo que os filmes também podem ser vistos como abrangências para se dialogar com o cotidiano. 
Do cinema de Soler, consecutivamente fixo e instável, movido pela necessidade - quase urgente, primordial, fundante - de ensejar temáticas e personagens sociais, sobre dramas perenes (racismo, migração, desaparecimentos históricos, institucionalizações sempre malsucedidas, disputas e invisibilidades reais diante de imaginários com toda a força), há um caminho reflexivo e exploratório. Caminho determinado a cotejar uma inapelável intersecção com a pintura, com a poesia mínima, afeito aos pequenos aforismos cinematográficos, aos "impulsos", fragmentos, metaforizações disponíveis como linguagens altruístas e colaborativas. ${ }^{14}$

Não obstante, o documentário também é um trabalho de reflexão, de acumulação de material, de estudo, de interpretação da realidade e de seu entendimento como textos visuais com aproximação histórica. Pequenos capítulos do repúdio e da inverossimilhança do esquecimento, como nos dois filmes sobre o Holocausto, Sobrevivir a Mauthausen (1975) e Francisco Boix (2000). ${ }^{15}$ Nesse sentido, o documentário se move sempre para fora, como a ideia de uma força centrífuga. Força, para Soler (2006), que se conjuga com a proposição testemunhal e a atitude reflexiva ante a forma fílmica (uso imagens com unidades narratológicas próprias, primeiros planos, micro relato, etc.). $\mathrm{O}$ documentário não termina, portanto, de constituir uma história do apêndice sobre as relações - e não as disputas, não os mascaramentos, no cinema do cineasta, entre poética e emancipação discursiva (dos sujeitos interpelados).

A imagem não nega, mas guarda seu traço material como uma coluna imaginal que se ancora, desde o início, ${ }^{16} \mathrm{com}$ uma proposta de pensar, expor, não divisar a questão de como os relatos se estruturam e são confirmados. $\mathrm{O}$ cinema de forte discussão social se entrelaça com o experimental (realidade como elemento narrativo), desde os seus princípios. Seu cinema de testemunhos também é, assim, cinema de arqueologias da inverossimilhança, onde as pausas são escritas dentro de uma memória que sabe relativizar pertenças (e arriscar relatos). Com isso, a preferência pelo estilo documentário parece adentrar mais na destruição do real, em desejar entendê-lo como uma representação que narra a própria experiência na estrutura do risco: agregar o social e perceber do que é feito sua perda. ${ }^{17}$

14. Às narrativas temporais subjacentes ao caminho escolhido em Apuntes para uma Odisea Soriana interpretada por Negros (2004), 20 Proposiciones para um silencio habitado (2007), Autorretrato (2007), Dialogos em la meseta con torero al fondo (2008), Historia (s) de España (2008), Los naufragos de la Casa Quebrada (2011), etc.

15. O primeiro anterior a Shoah (Claude Lanzmann, 1985) e claramente uma referência.

16. Será tu tierra (1965), 52 Domingos (1966), El largo viaje hacia la ira (1969), Filme sin nombre (1970), etc.

17. "Como homem de cinema que fui, sou e serei, sempre chamarei documentários meus trabalhos anclados na realidade dos fatos e sustentados sobre o testemunho das pessoas" (Soler, 2002: 17). 


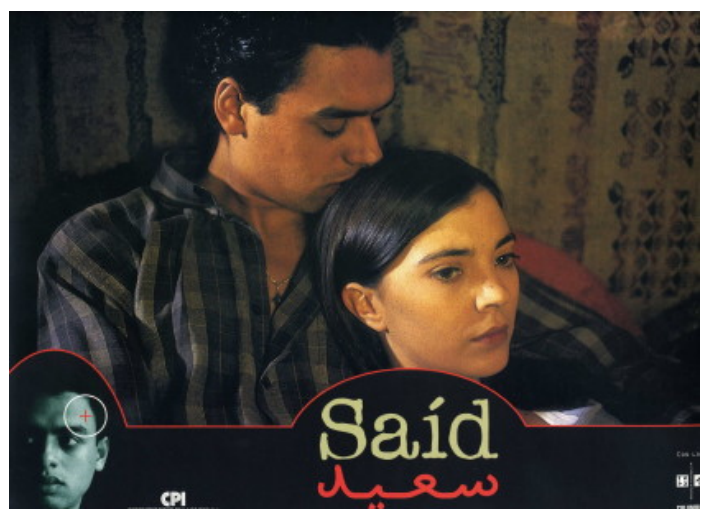

Figura 3. Fotograma de Saïd (1999)

Diante dos jogos de realidade e ficção em suas poucas narrativas ficcionais, como em Saïd (1999) e Lola vende cá (2000), os registros fílmicos parecem mediados pela capacidade em produzir risco e buscar visualidades. Elegíveis porque abertas ao campo do encontro, estas apontam diagramas do mundo em forma de enfrentamentos, gestos, subjetividades. Interpelam a essência do fotograma, que é mediação e significado. Buscam, como uma vontade de premência - de abundância, de perceber sem ser necessariamente nominado, de instruir sem autofagicamente consumir o imaginário - relacionar imagens e visões de mundo possíveis. Os filmes, nesse aspecto, ambicionam à relacionalidade que de outra forma o mundo (social, físico, indumentário, caracteriológico) não habilita. Seus filmes são espécies de escavações, menos trincheiras que galerias de relatos e forças de encontros, pontos de partida, intermitentes, abertos, possíveis porque o alegórico se trama com o etnográfico - e porque o etnográfico não tem nenhum receio em resistir pela intensificação e pela escuta. O cinema, nesse caso, passa de transgredir o real a emancipá-lo em palavra e corpo, em afeto e afeição, em olhar e ser olhado. O tempo é instruído pelo excesso e a liberdade através da sua fruição. Nesse âmbito, o posicionamento do cineasta parece importar mais do que tudo: estar presente sem perder presença, ouvir sem impedir escuta, ver sem deixar de enxergar.

O tempo do plano é a característica de um cinema de artesania e criação. Cinema aos pedaços, feitos de pequenos desencadeamentos instruídos por um reconhecimento essencial: parte-se de uma ideia que não vive solitariamente com o cineasta, com o etnólogo, com o observador emancipado. O filme é uma abertura ao contingente porque permite a oportunidade de se posicionar sempre uma e outra vez (aprender um novo ponto de posição). A autoria está 
na capacidade de colocar em andamento a ideia da circulação, da atitude de levar mais além à vontade de questionamento, de transferir para o outro uma relacionalidade que deseja fugir do excesso (de si) e, com isso, encontrar-se.

Nesse sentido, a encruzilhada estilística na trajetória do cineasta ao longo de mais de cinquenta filmes, revela-se uma busca, uma errância, uma vontade de desconfigurar, para aprender da relação. Entre anonimato e subjetividade, traços de uma fisicalidade da imagem que permite a coexistência de afetos e imaginários, de visões de mundo e mundos em irrupção, que precisam do jogo da visualidade (Max Aub: Un escritor en su labirinto, 2002; Del roig al blau, 2005; El hombre que sonreía a la muerte, 2006) que não podem ser esquecidos (Sobrevivir en Mauthausen; Francisco Boix), que devem transmitir ausência e sobreviver além da forma (Veinte proposiciones para un silencio habitado, 2007; Autorretrato, 2007; Dialogos em la meseta con torero al fondo, 2008; Los naufragos de la Casa Quebrada, 2011).

Ao longo de sucessivos giros (reflexivos, éticos e etnográficos, alegóricos e ensaísticos, testemunhais e criativos), um cinema de apelo à desconstrução prescritiva e a poética em compromisso. Um cinema de movimentos, interiores ao tentar exterioridades, para fora ao imergir em si mesmo: constantemente aberto ao lúdico e ao tentativo, filmes que partem do cotidiano e chegam (mais) à universalidade. Filmes, a saber, que se instruem de contingência e superam a objetificação sem poesia.

Um cinema, finalmente, da ontologia da significação intervalada pela presença e pelo traço, habitado pela expectativa de experiência, transcendido pelo fragmentário, sucessivo pelo engajamento - e determinado pelo desconforto. Em suma, um cinema que aprende da perda (a incapacidade em perder sem arriscar no encontro), mas que jamais almeja uma normatividade plena. Um lugar - o cinematógrafo - que se presencia numa membrana excedente, prisma do mundo de relações e jogos de pontos de vista. Um cinema de sala de espelhos e zona de (interstícios) de sentidos, mas que se instaura na filosofia documentarista (narrativas éticas, testemunhos estéticos), para, dentro do imprevisível, profanar o gesto - e demorar na escuta. 


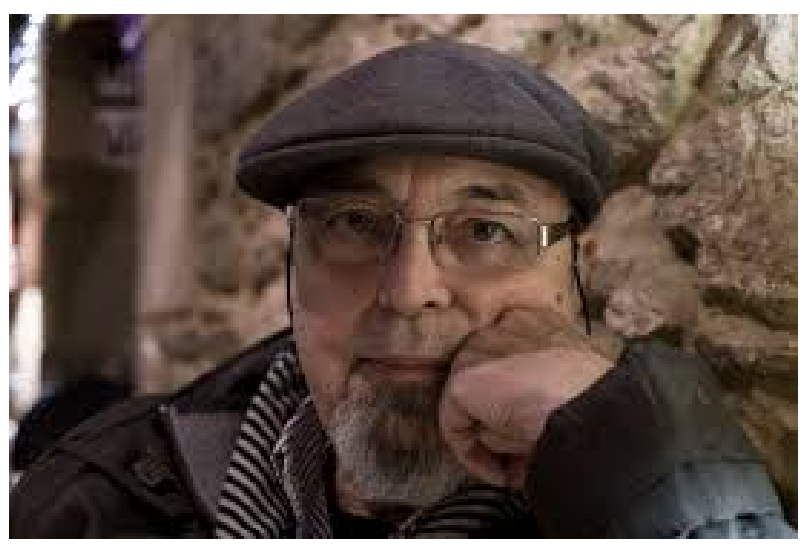

Figura 4. Llorenç Soler

Em Llorenç Soler, a imagem é o esconderijo do visível e o documentário é a destruição da realidade.

\section{Referências bibliográficas}

Català, J. M. (2012). Formas de la distancia: los ensayos fílmicos de Llorenç Soler. In M. Francés (org.), La mirada comprometida. Madrid: Biblioteca Nueva.

Comolli, J.-L. (2008). Ver e poder, a inocencia perdida: cinema, televisão, ficção, documentário. Belo Horizonte: Editora da UFMG.

Berzosa, A. (2012). Juegos de realidad y ficción en la obra de Llorenç Soler. In M. Francés (org.), La mirada comprometida. Madrid: Biblioteca Nueva.

Bourdieu, P. (1996). As regras da arte: gênese e estrutura do campo literário. São Paulo: Companhia das Letras.

Didi-Huberman, G. (2015). Remontages du temps subi: l'oeil de l'histoire. Paris: Editions de Minuit.

Francés, M. (org.) (2012). La mirada comprometida. Madrid: Biblioteca Nueva.

León, B. (s.d.). Contar historias reales: una radiografía de la narrativa de Llorenç Soler. In M. Francés (org.), La mirada comprometida. Madrid: Biblioteca Nueva.

Romaguera I.; Ramió, J. \& Soler, L. (2006). Historia crítica y documentada del cine independente em España: 1955-1975. Barcelona: Laertes. 
Soler, L. (1994). Llorenç Soler: dunha beira a outra. Galícia: Universidad de Santiago.

Soler, L. (1998). La realización de documentales y reportajes para televisión. Barcelona: CIMS.

Soler, L. (2002). Los hilos secretos de mis documentarios. Editorial CIMS.

Soler, L. (2006). El cineasta frente a un problema social: una reflexión a partir del filme "Ciudadanos bajo sospecha". In F. R. Neira, Cidadanía e documental - Ciudadanía y documental. Santiago de Compostela: Universidade de Santiago de Compostela.

Stratern, M. (2013). Fora de contexto: as ficções persuasivas da antropologia. São Paulo: Terceiro Nome. 